\title{
The Right to a Fair Trial
}

Galligan has noted how little is known about the practical operation and effect of the procedural principles of Article 6(1) ECHR. He argues that the dearth of empirical research and the absence of a comprehensive study of types of process covered by Article 6(1) ECHR make generalizations about its strength and weaknesses difficult to sustain. ${ }^{1}$

This chapter attempts to partially fill the gap identified by Galligan.

\subsection{Formulation and Importance of Article 6(1) ECHR}

Article 6 of the European Convention of Human Rights stipulates the following:

1. In the determination of his civil rights and obligations or of any criminal charge against him, everyone is entitled to a fair and public hearing within a reasonable time by an independent and impartial tribunal established by law. Judgment shall be pronounced publicly but the press and public may be excluded from all or part of the trial in the interests of morals, public order or national security in a democratic society, where the interests of juveniles or the protection of the private life of the parties so require, or to the extent strictly necessary in the opinion of the court in special circumstances where publicity would prejudice the interests of justice.

2. Everyone charged with a criminal offence shall be presumed innocent until proved guilty according to law.

3. Everyone charged with a criminal offence has the following minimum rights:

(a) to be informed promptly, in a language which he understands and in detail, of the nature and cause of the accusation against him;

(b) to have adequate time and facilities for the preparation of his defence;

1 Galligan, op. cit., p. 222. 
(c) to defend himself in person or through legal assistance of his own choosing or, if he has not sufficient means to pay for legal assistance, to be given it free when the interests of justice so require;

(d) to examine or have examined witnesses against him and to obtain the attendance and examination of witnesses on his behalf under the same conditions as witnesses against him;

(e) to have the free assistance of an interpreter if he cannot understand or speak the language used in court.

The importance and impact of this provision are often misunderstood and ignored. I argue that the right to a fair trial is the most important provision of the ECHR both in terms of the number of decisions adopted and the impact on the enforcement system. The right to life and the prohibitions against torture, slavery or illegal detention are all important components of a democratic state and their enforcement is essential for the well-being and development of the individual. However, fair trial is the transmission belt that ensures the smooth functioning of power, by presenting the problems that the individual encounters to the authority that has the competence, the tools and, hopefully, the will to solve it. When the mechanism of state power has a functioning fair trial transmission belt, access to justice and effective judicial review ensure that all the other rights guaranteed by the Convention - and by the constitutions of the members states - become real. Indeed, if the right to a fair trial is guaranteed in a member state, an individual who alleges that his right to life - or another right - has been breached can have his claim heard and compensation awarded by the competent authority. In other words, justice will be restored. If, on the other hand, the member state lacks the capacity, tools or will to enforce due process rights and blocks the transmission of individual concerns, rights remain empty words and the victim will either give up the idea of stateprovided justice altogether, by choosing a personal form of revenge, or will continue seeking to enforce it in an international forum.

This claim finds support both in numbers and in opinions. The yearly reports on the activity of the ECtHR show that almost all applications lodged with the Court raised an Article 6 complaint. Also, the majority of the cases delivered by the Court deal with the safeguards enshrined in the right to a fair trial. Thus, in 2018 , the right to a fair trial was at issue in $24.1 \%$ of cases in which a violation was found. ${ }^{2}$

2 ECtHR. Annual Report 2018. Available athttps://www.echr.coe.int/Documents/Annual_ report_2018_ENG.pdf accessed on 23 February 2021. 
The opinions concur. The Court itself has held that "the right to a fair trial holds so prominent a place in a democratic society that there can be no justification for interpreting Article $6 \S 1$ of the Convention restrictively". ${ }^{3}$

"An omnibus provision", the right to a fair trial "is a basic element of the rule of law and part of the common heritage, according to the Preamble, of the Contracting States". ${ }^{4}$

Ashworth has rightly noted that the right to a fair trial is part of a group of rights situated between non-derogable rights, such as the right to life, and qualified rights. He calls these rights 'strong rights', "to demonstrate that they have a strength which is not qualified to the extent that the rights in Article 8-11 are qualified". ${ }^{5}$ Ashworth notes that "although strong rights are less fundamental than the non-derogable rights, any arguments for curtailing a strong right must at least be more powerful than the kind of 'necessary in a democratic society' argument that is needed to establish the acceptability of interference with one of the qualified rights". 6

Flauss has argued that the right to a fair trial is a procedural guarantee which has increasingly developed the relevance of the substantive rights enumerated in the Convention. ${ }^{7}$

Speaking about the variety of disputes brought by applicants to the ECtHR, some authors have shown that a majority of cases brought to the Court indeed concern civil and criminal cases. However, "they also involve, to an extent that could not have been predicted, proceedings before civil and administrative tribunals and administrative decisions determining civil rights and obligations". ${ }^{8}$

\subsection{Influence of the Case-law of the ECtHR on Domestic Legislation}

Bates describes that there was a generalized conviction in the 1950s that the Convention had no future and that it was going to have a minor influence, if any, on domestic law. He states that

3 ECtHR. Perez v. France, application no. 47287/99, judgement of 12 Feb 2014, paragraph 64.

4 Rainey, Bernadette, Elizabeth Wicks and Clare Ovey. Jacobs, White \& Ovey: The European Convention of Human Rights (6th Edition). Oxford: Oxford University Press, 2014, p. 242.

5 Ashworth, Andrew. "Eroding the Structure of the European Convention." Current Problems in the Protection of Human Rights: Perspectives from Germany and the UK. Eds. K.S. Ziegler and P. M. Huber. Oxford: Hart Publishing, 2013, p. 33.

6 Ashworth, op. cit., p. 33.

7 Flauss, op. cit., p. 81.

8 Harris, D., M. O'Boyle, Ed Bates and C.M. Buckley. Law of the European Convention on Human Rights. Oxford: Oxford University Press, 2009, p. 202. 
there was a surprising lack of comment on the Convention from the most distinguished contemporary commentators in the international legal world at this stage. In fact, if one browses through the leading international law journals of the early 195 os one struggles to find references even to the fact that the ECHR had come into being, let alone any comment on the text itself and its significance. ${ }^{9}$

Even more, before the 1970s the few works that were published about the Convention came from a handful of authors that worked at the Council of Europe. ${ }^{10}$

The situation has changed since then. Although the ECtHR maintains a rather low profile, its case-law became increasingly known and respected. The ECtHR noted in Guincho that member states undertook the obligation of organising their legal systems so as to ensure compliance with the requirements of Article 6(1) ECHR, including that of trial within a reasonable time. ${ }^{11}$ In addition, as Rainey, Wicks and Ovey noted, the case-law of the ECtHR has had a significant impact. For applicants bringing claims to Strasbourg, a favourable decision can lead to criminal proceedings being reopened or to the award of damages. Perhaps more importantly, "states all over Europe have amended and improved their legal procedures to comply with the Court's rulings". ${ }^{12}$ They note that following the ECtHR's consistent approach to this matter, "the perennial problem of excessive length of proceedings is beginning to be addressed in a systematic fashion in a number of Contracting Parties". ${ }^{13}$

Bates offers a few examples of the law reforms instituted in the UK as a result of a violation found by the ECtHR. The Sunday Times prompted the introduction of the Contempt of Court Act 1981. ${ }^{14}$ Marckx led to a 1987 Act which amended various legal provisions relating to affiliation..$^{15}$ Young, James and Webster prompted new employment law legislation. ${ }^{16}$ And Sporrong

$9 \quad$ Bates, op. cit., pp. 9-10.

10 Bates, op. cit., p 10.

11 ECtHR. Guincho v. Portugal, application no. 899o/8o, judgement of $10 \mathrm{Jul}$ 1984, paragraph 38 .

12 Rainey, Wicks and Ovey, op. cit., p. 276.

13 Rainey, Wicks and Ovey, op. cit., p. 276.

14 ECtHR. The Sunday Times v. the United Kingdom [GC], application no. 6538/74, judgement of 26 Apr 1979 .

15 ECtHR. Marckx v. Belgium [GC], application no. 6833/74, judgement of 13 Jun 1979.

16 ECtHR. Young, James and Webster v. the United Kingdom [GC], applications nos. 7601/76 and $7806 / 77$, judgement of 13 Aug 1981. 
and Lönroth prompted new legislation concerning town and country planning. ${ }^{17}$

Violations of the right to a fair trial triggered numerous other changes on the domestic level. In order to highlight the impact of the ECtHR's case-law on the domestic legal landscape, the Council of Europe offers a web-catalogue of the most important cases, in addition to the work performed by the Council of Europe's Committee of Ministers. ${ }^{18}$

Thus, Airey prompted the Irish government to set up an independently administered legal aid scheme. ${ }^{19}$ Following a case of arbitrary detention in a psychiatric hospital, the Netherlands introduced new legislation instructing that, in all cases of involuntary admission to a psychiatric hospital, the patient has the right to be heard by a court. ${ }^{20}$ The law was also changed so that patients who are involuntarily admitted to a psychiatric hospital do not automatically lose control over their property. ${ }^{21}$

In Rumpf, the ECtHR found a violation against Germany of the right to a fair trial on account of the fact that the applicant's administrative dispute lasted for 13 years and 5 months. ${ }^{22}$ This judgment and others led to a new law in 2011 to tackle unreasonable legal delays. It gave applicants the opportunity to challenge the slow pace of proceedings and ask for a remedy. It also provided for a right to compensation. These reforms allowed Germany to overcome a longstanding structural problem concerning remedies for excessively long civil proceedings. $^{23}$

In a case against Andorra, the ECtHR found a violation of the right to a fair trial due to the fact that the applicant could not lodge a complaint to the Constitutional Court without the prior approval of the State Council. ${ }^{24}$ As a result of this case, the legislation of Andorra has changed to allow everyone the right to lodge complaints with the Constitutional Court. ${ }^{25}$

17 ECtHR. Sporrong and Lönnroth v. Sweden, applications nos. 7151/75 and 7152/75, judgement of 23 Sep 1982, pp. 151-152.

18 Web-catalogue available at https:/www.coe.int/en/web/impact-convention-humanrights/right-to-a-fair-trial accessed on 23 February 2021.

19 ECtHR. Airey v. Ireland, application no. 6289/73, judgement of 9 Oct 1979.

20 ECtHR. Winterwerp v. the Netherlands, application no. 6301/73, judgement of 24 October 1979 .

21 Council of Europe. Resolution of the Council of Europe's Committee of Ministers DH (82) 2.

22 ECtHR. Rumpf v. Germany, application no. 46344/o6, judgement of 2 Sep 2010.

23 Council of Europe. Resolution of the Council of Europe's Committee of Ministers DH (2013) 244

24 ECtHR. Millan $i$ Tornes v. Andorra, application no. 35052/97, judgement of 6 July 1999 .

25 Council of Europe. Resolution of the Council of Europe's Committee of Ministers DH (99) 721. 
Another important development took place in France, where, following Kress, the French Cour de cassation broke an old continental tradition and excluded the Advocates General from the Court's preparatory debates and from the judicial deliberations. ${ }^{26}$

Lastly, following a few cases against Switzerland, a reform of panel procedures was triggered resulting in the separation of the investigating and ruling judges in the Canton of Berne.

\subsection{External Influences on the Case-law of the ECtHR}

The right to a fair trial is a provision whose interpretation and enforcement have been shaped by the same events that shaped the destiny of the Contracting Parties to the Convention. In many ways this provision has a European destiny and reflects important legal developments at the domestic level. The right to a fair trial is a mutable provision that has allowed historical events to inform its substance, offering every generation of lawyers the opportunity to show where the mechanism of governmental power is lacking speed or essential parts.

Accession of new member states to the ECHR and their changing constitutional landscapes, migration and modernization of life, as well as the military conflicts in which member states are involved are all factors which raise questions about the interpretation of the right to a fair trial. For the member states leaving behind dictatorial pasts, questions about how to organize and balance the branches of government have been essential and the ECtHR did not fail to provide answers. Recently, the process of European integration and the accession of the European Union to the ECHR raised concerns about the human rights protection system in Europe and the coexistence of the ECtHR and the CJEU.

A point worth serious mention is that the ECtHR has not always been on a quest for enhancing its jurisdiction, as it is sometimes proposed. A preconceived view of the ECtHR is that it is a rights-creating or rights-enhancing machine. The facts speak to the contrary. The Court follows a refined and careful approach to rights interpretation and this is especially true in relation to the right to a fair trial. On the one hand, the large number of applications originating from all member states concerning the right to a fair trial indicates a

26 ECtHR. Kress v. France, application no. 39594/98, judgement of 6 June 2001. See also, Andriantsimbazovina, Joël. "Savoir c'est rien, imaginer est tout: Libre conversation autour de l'arrêt Kress de la Cour européenne des droits de l'homme." Recueil Dalloz, Chronique (2001): pp. 2611. 
general dissatisfaction with the manner in which justice is delivered on the domestic level. On the other hand, the Court is not in a hurry to translate this dissatisfaction into violations of the Convention and to therefore order the governments to change legislation or practice. Rather, the Court alternates between periods of expansion, stagnation and even contraction.

Thus, the evolution of the right to a fair trial is closely linked to the evolution of the Court itself. The ECtHR is a successful international tribunal: its decisions are being implemented by the member states and its case-law is quoted by other international tribunals and during human rights law classes offered at numerous universities. This success, however, did not come easy. Rather, the ECtHR has built its reputation slowly and carefully by choosing only a handful of cases for consideration on their merits during the first years of its existence. Many of the initial cases of the Court dealt with the right to a fair trial. Indeed, this provision offered the Court the opportunity to spell out some of the most important general principles concerning the interpretation of the Convention. This original case-law impresses through its maturity and its capacity to resist the moods and fashions of changing times.

Thus, the case Golder concerned a serious disturbance in the prison where the applicant was serving his term and in which he was suspected of having been involved. ${ }^{197}$ The applicant decided to lodge a civil action for libel against the prison officer who accused him of having been involved in the disturbance. When the applicant's request to the Home Secretary for permission to consult a solicitor with a view to bringing the civil action for libel was refused, the applicant complained at the ECtHR about a breach of his right to have access to a court.

The Court held that

it was not for the Home Secretary himself to appraise the prospects of the action contemplated; it was for an independent and impartial court to rule on any claim that might be brought. In declining to accord the leave which had been requested, the Home Secretary failed to respect, in the person of Golder, the right to go before a court as guaranteed by Article 6 para. 1 (art. $6-1) .{ }^{27}$

In Airey, the applicant complained about the impossibility to separate judicially from her husband. She maintained that, since the prohibitive cost of

27 ECtHR. Golder v. the United Kingdom, application no. 4451/70, judgement of 21 Feb 1975, paragraph 40. 
litigation prevented her from bringing proceedings before the High Court for the purpose of petitioning for judicial separation, there has been a violation of the right to a fair trial.

The Court agreed with the applicant and found that

the Convention must be interpreted in the light of present-day conditions and it is designed to safeguard the individual in a real and practical way as regards those areas with which it deals. Whilst the Convention sets forth what are essentially civil and political rights, many of them have implications of a social or economic nature. The Court therefore considers, like the Commission, that the mere fact that an interpretation of the Convention may extend into the sphere of social and economic rights should not be a decisive factor against such an interpretation; there is no water-tight division separating that sphere from the field covered by the Convention. ${ }^{28}$

In Engel and Others, the applicants were military conscripts. ${ }^{29}$ They were punished for breach of discipline and were sentenced to a few days of light arrest. Their attempts to contest the disciplinary measure were unsuccessful. They complained at the Court about the unfairness of the disciplinary proceedings in which they were involved.

Thus, before the accession of the Eastern European members, the Court had considered a wide range of issues relating to civil and criminal justice in Western Europe.

The accession of the Eastern European states to the Council of Europe and the European Convention of Human Rights provided the ECtHR with a new impetus to consider the right to a fair trial. The exit from totalitarian regimes was marked by an upsurge of applications to the Court originating from Eastern European countries and by a generalized contestation of the power-exercising institutions. Also, if previously the Court was dealing with states that had a long record of democratic practices, after the 199os, the case-law of the Court contributed to the creation and development of these practices in countries that were fully involved in the process of democracy-building for the first time in their history.

More and more cases were lodged at the Court starting in the 199os to the point that the Court could not handle them all. At the beginning of 2012, there

28 Aireyv. Ireland, quoted above, paragraph 26.

29 ECtHR. Engel and others v. the Netherlands, application no. 5100/71, judgement of 8 Jun 1976. 
were 151,600 cases pending before the ECtHR. ${ }^{30}$ Many of these cases were repetitive and concerned systemic problems, that is, they required the implementation, reformulation or cancellation of a domestic statute.

In the context of a generalized outcry against the state of justice in Europe and the Court's incapacity to deal with its increasing backlog, the Court put forward a strategy for dealing with systemic problems. More precisely, the Court launched a new procedure meant to address simultaneously all cases raising identical legal problems. This new procedure - called the pilot procedure - is often employed in relation to fair trial issues such as non-execution of judgments or lengthy proceedings. ${ }^{31}$

The process of European integration raises new questions concerning the interpretation of the right to a fair trial. All members of the European Union are parties to the Convention. At the same time, the European Union itself is not a party thereto, at least not until its accession to the Convention is concluded. This situation raises questions about the institutional position of the ECtHR within the Union, about the future of fundamental rights in the Union and about respect of the right to a fair trial by the Union's institutions.

30 ECtHR. Annual Report 2012, p. 149. Available at https://www.echr.coe.int/Documents/ Annual_report_2012_ENG.pdf accessed on 23 February 2021.

31 ECtHR. The Pilot-Judgement Procedure: Information Note Issued by the Registrar. Available at https://www.echr.coe.int/Documents/Pilot_judgment_procedure_ENG.pdf accessed on 23 February 2021. 